\title{
Utilization of Public Relations Program in Educating the Millennials About Papua-Indonesia Separatism Issue
}

Dewi Febrina Iriani ${ }^{1}$, Gaby Mariska Runtu ${ }^{2}$, Santo Medy Wibisono ${ }^{3}$ and Bambang Sumaryanto ${ }^{4}$

1,2,3,4 Institut Komunikasi dan Bisnis LSPR, Jakarta, Indonesia

\begin{abstract}
The issue of Papuan-Indonesian separatism is not new in Indonesia, and this has become the Ministry of Foreign Affairs' concentration to deal with. In this case the project planners believe that there is a humanitarian and dignified perspective that needs to be improved by the government. Therefore, the measure needs a Public Relations approach as an effort to support government programs in overcoming the issue of Papua-Indonesia separatism. The method employed in this research is to use strategic planning public relations by Ronald Smith, which consists of 9 steps in 4 phases. The concepts used in this project are Public Relations, Online PR, Social Media, and Event Design. By approaching PR through social media programs and events, the project planners claimed to be able to approach millennials to shape their awareness of Papua, so they have a good image of Papua. This will have an impact on the spread of positive Papuan issues on social media, which was dominated with negative issues regarding separatism. The success of the program will be evaluated by the number of participants involved in the event, social media followers, and positive news spread on social media.
\end{abstract}

Keywords: separatism; strategy; public relations; social media; event

\section{Pemanfaatan Program Public Relations Dalam Mengedukasi Kaum Milenial Mengenai Isu Separatisme Papua-Indonesia}

\begin{abstract}
ABSTRAK
Isu separatisme Papua-Indonesia bukan hal yang baru di Indonesia, dan hal ini sudah menjadi konsentrasi Kementerian Luar Negeri untuk menangani isu tersebut. Perencana proyek melihat ada sudut pandang kemanusiaan dan martabat yang perlu ditingkatkan oleh pemerintah. Sehingga dalam hal ini, perlunya pendekatan Public Relations sebagai upaya untuk mendukung program pemerintah dalam mengatasi isu separatisme Papua-Indonesia. Metode yang dilakukan untuk melakukan proyek ini adalah dengan menggunakan strategic planning public relations oleh Ronald Smith, yang terdiri dari 9 langkah dalam 4 fase. Konsep yang digunakan dalam proyek ini adalah Public Relations, Online $P R$, Social Media, dan Perancangan Event. Dengan melakukan pendekatan PR melalui program social media dan event, perencana proyek mampu mendekati generasi millennials untuk membentuk kesadaran mereka terhadap Papua, sehingga mereka memiliki image yang baik terhadap Papua, dan hal ini akan berdampak pada penyebarluasan isu positif Papua di social media, yang tadinya didominasi dengan isu negative mengenai separatisme. Keberhasilan program akan dievaluasi dengan jumlah peserta yang terlibat dalam event, jumlah followers media sosial, serta jumlah berita positif yang tersebar di media sosial.
\end{abstract}

Kata kunci: separatisme; strategi; public relations; social media, event 


\section{INTRODUCTION}

Papua is a strategic and competent region to compete in the Pacific region. It is currently facing great opportunities because of its strategic position as a potential hub for the Indo-Pacific region. Many opportunities can actually be achieved, including increasing trade and cooperation between Indonesia and Papua New Guinea as well as other pacific countries through Papua . This, of course, should be a big concern for the Indonesian government, to continue to develop Papua ("Papua: A Growing Hub on the Indo-Pacific Track," 2016.). Another concern is to pay special attention to Papua, and minimize negative issues regarding Papua. This matter needs to be prioritized by the Ministry of Foreign Affairs because it is related to diplomatic issues.

The biggest and dominating issue in Papua is separatism. The issue of separatism has indeed become a very long and protracted problem. The issue of separatism arose because of the existence of provocative groups who voiced injustice towards equitable development in Indonesia. Some people feel that the government does not pay special attention to Papua although Papua feels that it has sufficient resources, but is not optimized. This made, some individuals decided to fight for independence from Indonesia.

In an effort to reduce this issue, the government continues to take an approach, namely carrying out development so that Papua has the same rights as other regions in Indonesia. In fact, the Indonesian government has recently given special treatment to Papua, such as the construction of facilities and infrastructure in tourism locations in Papua, to the border areas of the country in Papua. In addition, a major government project that has attracted a lot of public attention is the equal distribution of fuel prices in Papua. However, many people still do not know this causing many people to think that Papua is still lagging behind, and the government has not been optimal in developing Papua. Therefore, a program is needed to communicate this achievement to the community.

The wrong perception about Papua is evident from the case of the Head of BEM UI Handing the "Yellow Card" to Jokowi (Kompas.com, 2018). In his action, Zaadit Taqwa, Chairman of Bem UI gave President Jokowi a yellow card as a form of warning for the problems that occurred in Papua, among others: First, related to malnutrition in Asmat, Papua to be resolved immediately by the government. Avoiding cases like this from happening, of course, a communication program is needed to the public to better understand the actual conditions that occur.

The most strategic public to be targeted for communication programs are millennials. This has an effect on how millennial groups voice their opinions to the wider public. Through this project, the authors offer a program to assist the government in reducing the Papua-Indonesia problem, namely a millennial education program on the issue of Papua separatism. Young 
people have a big role in creating diplomatically positive image of Indonesia. In addition, young people are also the largest internet users. In using the internet, people can freely obtain and disseminate information. In particular, millennials, or more often called "young people today" are people who are free to express themselves. They tend to be easy and fast in obtaining information, but are not wise in responding to the information.

According to the latest survey by the Association of Indonesian Internet Service Providers (APJII) in October 2016, 80 percent or around 25 million Indonesian internet users are those aged 25-29 years and around 72 percent of users are aged 30-34 years. In terms of work, the dominant internet users in Indonesia are private employees around 88 percent and students 89 percent. The phenomenon of internet use today is that internet users in Indonesia are hungry for the latest information. The survey shows that 31.3 million users use updating information as the main reason for accessing the internet. This figure exceeds the number of users who access the internet for work reasons (27.6 million) and just to fill their spare time (17.9 million).

Based on this explanation, the project planners will offer an educational program for millennials to the Ministry of Foreign Affairs in overcoming the issue of Papua separatism. Cutlip, Center, and Broom (2011) define Public Relations as the management function which evaluates public attitudes, identifies the policies and procedures of an individual or an organization with the public interest, and plans an excutes a program of action to earn public understanding and acceptances. From this definition, it is evident that PR is an important management function for companies to gain public support. In an effort to reduce the issue of Papua Separatism, the project planners educate millennials to create perceptions through a public relations approach about Papua.

\section{METHODS}

In this project we use the Smith's (YEAR???) Strategic Planning Public Relations, which consists of 9 steps in 4 Phases. These steps start from research, determining communication objectives and tactics, to planning evaluations. 
Figure 1 Planning Step of The Project

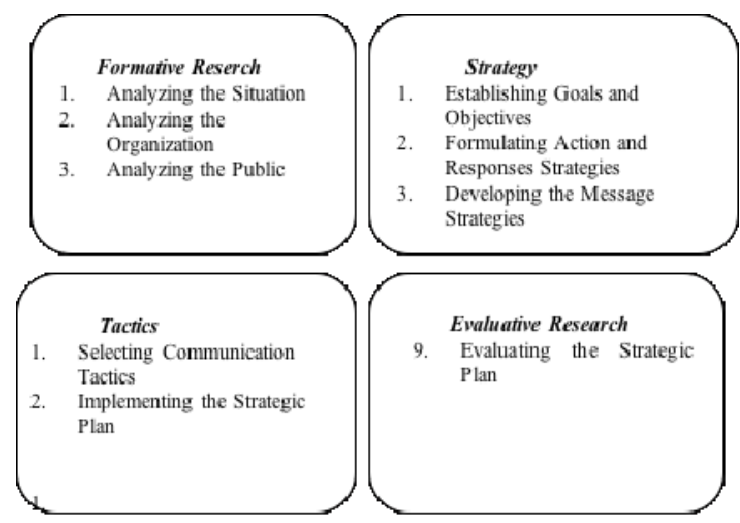

Source: Kotler and Lee, 2012

In conducting a PR program to educate millennials, marketing principles and techniques are needed to determine the target audience and program objectives. This includes changing the behavior of the audience, which previously did not understand the issue of Papua separatism, to understand it. For this reason, the project planners also use the concept of Social Marketing to see how to (a) influence behavior, (b) utilize a systematic planning process that applies marketing principles and techniques, (c) focus on priority target audience segments, and (d) provide positive benefits. for society (Kotler \& Lee, 2012).

\section{RESULT AND DISCUSSION}

To analyze the existing situation, the project planners carried out research on the news on the issue of Papua separatism. To deepen the research, the project planners also conducted interviews one of the observers on the Papua issue.

\section{Analyzing the Organization}

The organization we chose to undertake this project is the Ministry of Foreign Affairs. The ministry was selected because it deals with diplomatic issues. To analyze the organization, we conducted a SWOT (strength, weakness, opportunity, threat) analysis. In analyzing SWOT, it is influenced by three aspects, namely internal environmental, public perception and external environmental (Smith, 2005, p.28). In determining the SWOT, the project planners also conducted in-depth interviews and document analyses on previous activities carried out by the Ministry of Foreign Affairs.

\section{Analyzing the Public}

In this step, the project planners will identify the public who are affected and involved in this project. As previously explained, young people are the main target of this program. Young people have a big role in creating positive image of Indonesia. However, not many young people understand the issue of Papua separatism despite the fact that correct understanding is very influential and related to nationalism and diplomacy. 


\section{Establishing Goals and Objectives}

The aim of this program is Reputation Goals Management, which is to develop a Public Relations strategy for the Ministry of Foreign Affairs to educate millennials about the issue of Papua separatism.

\section{Formulating Action and Responses Strategies}

In this project, the project planners agreed to create a public relations strategy with the title "What's up Papua," which aims to educate millennials about the issue of Papua separatism. This campiagn in intended for millennials to have a new perception of issues and get briefings to be ready to become informal diplomats.

\section{Developing the Message Strategies}

The message to be communicated in this program is that the government has optimized the development program for Papua in order to reduce the issue of Papua separatism.

\section{Strategy and tactics}

The communication tactic we use in this project is an Educational Program for Millennials through Events and Social Media. The event, entitled "What's up Papua," is a discussion activity for millennials with diplomats and observers of the Papua issue. The event will also hold campaign collaborations with event participants to share the results of their discussions through social media. This program will be implemented within one year.

\section{Evaluation}

In evaluating the program, the project planners will periodically check on:

- Number of participants in the "What's up Papua" discussion forum

- Total Influencers who are members of the Collaborations Campaign

- Number of posts with hashtag \#whatsapPapua every month

- The number of followers on each social media account

- Number of Likes and Comments on each social media account

- Total media publications during the activity

\section{CONCLUSION}

Public Relations "What's up Papua" is a program to educate millennials to have the correct perception of the issue of Papua separatism due to their lack of knowledge on the issue of Papuan-Indonesian separatism and their number as the largest internet users. This Millennial Education Program uses Events and Social Media as the main tools to reach young people. Through the event, young people were given the opportunity to talk and discuss with stakeholders on the issue, namely Ministers, Diplomats, and also observers of Papuan Issues. The goal of the project is for young people to be equipped and have the correct perception of the issues so that they can be prepared to become informal diplomats. In addition, through influencers, project planners of works also use social media as a means to disseminate information as it is one of the most effective communication tools in this modern era. The hashtags \#whatsupapua, \#indonesiaisus, and \#kitaindonesia are also used in disseminating information on social media.

\section{REFERENCES}


Ainiyah, Nur (2018). Remaja Millenial Dan Media Sosial: Media Sosial Sebagai Media Informasi Pendidikan Bagi Remaja Millenial. JPPI, 2(2), 221-236.

Cao, Y. (2010). Meeting the Millennial College Students: Examining Their Social Media Usage and Establishing Effective Strategies (Paper, University of La Verne). Diperoleh dari http://www.cair.org/wp-content/uploads/sites/474/2015/07/ SocialMediaandCollegeStrategy_Posting.pdf

Cutlip, Scoot M., Allen H. Center, dan Glen M. Broom. (2011). Effective Public Relations, Edisi Kesembilan. Jakarta: Kencana.

Hutahuruk, A (2017). Digital citizenship: sebagai upaya meningkatkan kualitas pembelajaran sejarah di era global. 2(2), 01-06.

Kaplan, Andreas M \& Michael Haenlein. (2010). Users of the World, Unite! The Challenges and Opportunities of Social Media. Business Horizons, 53, hlm 59-68.

Kirksey, E. S \& Roemajauw, J. A. (2010). The Wild Terrorist Gang: The Semantics of Violence and Self-determination in West Papua. Oxford Development Studie, 30(2), 189-203.

Nainggolan, P (2015). Aktivitas internasional gerakan separatisme papua. 19(3), 181-199. Diperoleh dari https://jurnal.dpr.go.id/index.php/kajian/article/view/555

Noor, A. (2013). Manajemen Event. Bandung: Alfabeta.

Nova, Firsan. (2011). Crisis Public Relatons Bagaimana PR Menangani Krisis Perusahaan. Jakarta: Raja Grafindo Persada.

Popescul, D, \& Georgescu, M. (2018). Generation Y Students in Social Media: What Do We Know about Them?. Alexandru Ioan Cuza, 74-81.

Saefudin, H.A. (2008). Diplomasi publik organisasi nonpemerintah dalam membangun citra Indonesia: Studi kegiatan “koalisi untuk kebebasan informasi”. Mediator, 70-88.

Saliu, H. (2017). The new nature of cultural diplomacy in the age of online communication.

Journal of Media Critiques, 88 100. doi: 10.17349/JMC117206

Smith, R. (2005). Strategic Planning for Public Relations. New Jersey: Lawrence Erlbaum Associate.

Temaluru, T. (2018). Kepentingan Vanuatu Dalam Usaha Pemerdekaan Papua (Tesis Universitas Airlangga). Diperoleh dari http://journal.unair.ac.id/download-fullpapersjahiff7d4e27a0full.pdf

Tom Watson \& Paul Noble. (2007). Evaluating Public Relations; A Best Practice Guide To Public Relations Planning, Research and Evaluation (2nd ed.). London: Kogan Page Limited.

Vaxevanidou, M. (2016). Public diplomacy as a tool to change the image of a country in crisis. Journal of Media Critiques, 112-119. doi:10.17349/JMC116207

Pelapor Khusus Dewan HAM PBB Terkesan dengan Fasilitas Pelayanan Kesehatan Berbasis Kemitraan di Papua. Retrivied, January 10, 2018 from https: //www. kemlu.go.id/id/ berita/ Pages / Pelapor -Khusus-Dewan-HAM-PBB-terkesan-dengan-fasilitas- 
pelayanan-kesehatan-berbasis-kemitraan-di-Papua.aspx

Generasi Millennial Indonesia: Tantangan dan Peluang Pemuda Indonesia. Retrivied, January 10, 2018 from http://alvara-strategic.com/generasi-millennial-indonesia-tantangan-danpeluang-pemuda-indonesia/ 